\title{
PREFACE AND ACKNOWLEDGEMENTS
}

The increase in research in women's history in recent years has revealed the importance of women's role in society. Women of the nobility and gentry often found themselves thrust into positions of influence and power as a result of marriage, widowhood, or the accidents of inheritance. The purpose of the present collection of documents is to show the range of interests and activities among this group of women, and by taking the period 1066-1500 it is possible to trace both continuity and change in their responsibilities and relationships within and outside their families. Some of the sources for medieval women's history have long been known, such as the Paston and Stonor Letters. Many of the documents, however, concerning family, household and estates, and religious and cultural attitudes, remain in manuscript, and deserve to be more widely known. Only by careful assessment of such evidence can a full picture of the women of the nobility and gentry be built up.

In working on this book I have incurred a number of debts. I especially want to thank Janet Nelson, who invited me to contribute to the Manchester Medieval Sources series, and the staff of Manchester University Press for their advice and help. Paul Brand, Nancy Edwards, Paul Fouracre, Jeremy Goldberg, Ray Powell and Martin Stuchfield have drawn my attention to particular sources, and discussed various aspects of the lives of medieval noblewomen. Any remaining mistakes are mine. I would also like to thank the staff of the Borthwick Institute, University of York, the British Library, Lambeth Palace Library, the Norfolk Record Office, and the Public Record Office for their help and for permission to publish documents and translations of documents in their care. Material held by the Public Record Office is Crown copyright and is reproduced with the permission of the Controller of Her Majesty's Stationery Office. The investigation of sources is a fascinating process; it is hoped that the collection will provide an insight into the riches of documentation which can be much further explored.

Goldsmiths College, London

October, 1994 